ГУМАНІТАРНО-ФІЛОСОФСЬКИЙ АСПЕКТ ФОРМУВАННЯ ПРОФЕСІЙНОÏ КОМПЕТЕНТНОСТІ СТУДЕНТА У ВИЩІЙ ТЕХНІЧНІЙ ШКОЛІ

\title{
HUMANITARIAN-PHILOSOPHICAL ASPECT OF FORMATION OF STUDENT PROFESSIONAL COMPETENCE IN HIGHER TECHNICAL SCHOOL
}

Стаття присвячена одній з актуальних проблем підготовки майбутніх фахівців технічного профрілю, а саме фрормуванню професійної компетентності гуманітарними та фрілософфськими підходами. Зокрема, розкривається сутність таких понять, як «професійна компетентність», «гуманізація та гуманітаризація технічної освіти», «культурологічний складник формування просресійної компетентності студента». Увага зосереджується на теоретичних основах розвитку та орормування профессійної компетентності. Зроблено аналіз наукових уявлень про явище «професійна компетентність», що передбачають вирішення таких завдань: аналіз наявних визначень понять «компетентність», «професійна компетентність»; вивчення структури просресійної компетентності особистості; визначення ролі гуманітарних дисциплін під час підготовки студентів; визначення і обгрунтування їх фрункцій у прочесі життєдіяльності особистості. Студент намагається знайти своє місце в житті відповідно до власних уподобань, інтересів та можливостей. I тільки компетентнісний підхід спрямований на саморозвиток і самовиховання студента, уміння самостійно осмислювати різні поняття, правила, теорії, формування пізнавальних, комунікативних, організаційних умінь, креативного способу мислення. Використання знань на практиці сприяє більш цілісному уявленню про світ та його взаємозв'язки. Компетентність означає загальну здатність молодої людини до профресійної праці й успішної життєдіяльності, що грунтується на здобутих знаннях, уміннях, досвіді та цінностях, здатність до продуктивного здійснення життя як індивідуального життєвого проєкту. Профресійна компетентність людини є складником життєвої компетентності. Структура професійної компетентності включає: професіійні знання і професійне мислення; відповідні вміння і навички, практичний досвід використання знань у конкретних ситуаціях; особистісні якості (професійну творчість, зацікавленість у результатах своєї роботи, позитивну мотивацію, ініціативу, прагнення до профресійної самореалізаціі); до базових компетентностей просресійної підготовки належать: загальнонаукові; соціально-економічні; громадянсько-правові; інформаційно-комунікативні; політехнічні; спеціальні. Просресійна компетентність розуміється як інтегративна система властивостей якостей особистості, професійних знань, умінь, навичок, здібностей виконання фрахової діяльності на високому рівні з використанням суспільно відомих і важливих, адаптованих компетениій, засобів, методів та досвіду, що характеризує відповідальність, дієву обізнаність і загальну освіченість, спрямованість на перспективу й ефективність у роботі, забезпечує впевненість і здатність досягати прогнозованих результатів.

Висвітлюються структурні компоненти, критерії, показники та рівні сформованост досліджуваного явища. На основі аналізу педагогічної літератури обірунтовується методика фоормування професійної компетениії. Зазначається також, що концепиія дослідження забезпечується єдністю мето- дологічного, теоретичного та методичного аспектів.

Ключові слова: гуманізація, гуманітаризація, фрілософрьький складник, професійна компетентність, заклад вищої освіти тех нічного профрілю, студент.

The article is devoted to one of the topical problems of training future specialists in the technical profile, namely the formation of professional competence in humanitarian and philosophical approaches. In particular, the essence of such concepts as professional competence, humanization and humanization of technical education, cultural part of the formation of student's professional competence is revealed. The focus is on the theoretical foundations of developing and developing professional competence. The analysis of scientific ideas about the phenomenon of "professiona competence", which provide the solution of the following problems; analysis of existing definitions of the concept of "competence", "professional competence"; studying the structure and professional competence of the individual; determining the role of the humanities in student preparation, definition and justification of their functions in the process of life of the individual. The student tries to find his place in life according to his own preferences, interests and opportunities. And only a competent approach is aimed at self-development and self-education of the student, the ability to independently understand different concepts, rules, theories, formation of cognitive, communicative, organizational skills, creative way of thinking. The use of knowledge in practice promotes a more holistic view of the world and its interconnections. Competence means a young person's overall ability to work professionally and successfully, based on his/her knowledge, skills, experience and values, and the ability to make a productive life as an individual life project. A person's professional competence is a component of vital competence. Structure of professional competence: professional knowledge and professional thinking; relevant skills and practical experience of applying knowledge in specific situations; personal qualities (professional creativity, interest in the results of their work, positive motivation, initiative, desire for professional self-realization). The basic competences of vocational training include: general science; socio-economic; civil law; information and communication; polytechnic; special. Professional competence is understood as an integrative system of personality traits and qualities, professional knowledge, skills, abilities, high-level professional activities, using socially known and important, adapted competences, tools, methods and experience, which characterize responsibility, effective awareness and awareness, a focus on prospect and performance, provides confidence and the ability to achieve projected results.

Structural components, criteria, indicators and levels of formation of the studied phenomenon are highlighted. Based on the analysis of the pedagogical literature, the methodology of forming professional competence is substantiated. It is also noted that the concept of research is ensured by the unity of methodological, theoreti$\mathrm{cal}$ and methodological aspects.

Key words: humanization, humanization, philosophical component, professional competence, institution of technical education higher education, student. 
Постановка проблеми у загальному вигляді. Складниками компетентності особистості є: компетентності стосовно себе як суб'єкта життєдіяльності (збереження свого фрізичного і психічного здоров'я, самоповага, розуміння свого місця в житті, володіння соціально-правовими основами поведінки в громадянському суспільстві, самовдосконалення та саморозвиток, прагнення до успіху, постановка адекватних життєвих цілей); компетентності стосовно взаємодії 3 іншими людьми (соціальна відповідальність, навички ефективного спілкування, уміння налагоджувати близькі та ділові взаємини, суспільний інтерес, уміння вибирати адекватні способи взаємодії з різними людьми залежно від ситуації, самоконтроль поведінки); компетентності стосовно діяльності в усіх її видах (навчання, спорт, профресія, всі практичні вміння і досвід).

Сучасна особистість має бути здатна і готова до конструктивного досягнення успішної життєдіяльності в мінливих суспільно-економічних умовах, самостійного і свідомого вирішення складних життєвих завдань, породжених інорормаційними, економічними, соціальними, політичними, культурно-релігійними процесами третього тисячоліття. Постає необхідність у життєвій компетентності особистості, її здатності успішно розв'язувати власні життєві проблеми, брати продуктивну участь у розв'язанні суспільних проблем. Розвиток життєвої компетентності особистості виступає умовою як ії̈ успішної, гармонійної життєдіяльності, так і профресійної компетентності, конструктивного перетворення і гармонійного розвитку суспільства.

Компетентність - це специфічна здатність, яка дає змогу ефективно розв'язувати проблеми, що виникають у реальних ситуаціях життя. У людини мають бути певні знання - інструменти, особливі способи мислення й життєві навички. Нова парадигма української освіти передбачає вдосконалення підготовки фрахівця, становлення його як профресіонала, глибоко освіченого у своїй галузі знань.

Нині спостерігається потреба у висококваліфікованому фрахівцеві, який із перших кроків добре орієнтується у виробничих технологіях і системах, самостійно знаходить та аналізує інфрормацію, раціонально використовує отриманий досвід для успішного вирішення професійних завдань і проблем. Рівень якості інженерної освіти є показником сорормованості професійної компетентності випускника. Моделюючи зміст, види, фрорми професійної роботи інженера та створюючи виробниче середовище важливо враховувати характер і особливості конкретного напряму галузевої діяльності інженерно-технічного працівника [1, с. 13].

Аналіз останніх досліджень і публікацій свідчить, що проблемі шляхів орормування профресійних компетентностей були присвячені роботи В.П. Бездухова, М.К. Будникова, О.М. Дахіна, Б.Д. Ельконіна, А.К. Маркова та ін. Досліджують та впроваджують сучасні методи розвитку компетентностей А.В. Василюк, О.В. Овчарук, О.І. Пометун, Н.Г. Ничкало, Н.В. Щербак, В.Г. Кремінь.

Основу компетентності фрахівця, на думку сучасних науковців О.О. Бодальова, В.І. Жукова, Л.Г. Лаптєва, В.О. Сластьоніна та інших, становлять: компетентність діяльності, спілкування і саморозвитку. Профресійна компетентність - це професійна підготовка і здатність суб'єкта праці до виконання завдань і обов'язків діяльності, міра й основний критерій його відповідності вимогам профресійної діяльності.

Виділення не вирішених раніше частин загальної проблеми. Профресійна компетентність людини є складником життєвої компетентності. Структура профресійної компетентності включає: професійні знання і профресійне мислення; відповідні вміння і навички, практичний досвід використання знань у конкретних ситуаціях; особистісні якості (професійну творчість, зацікавленість у результатах своєї роботи, позитивну мотивацію, ініціативу, прагнення до профресійної самореалізації). Бути компетентним - значить уміти мобілізувати в такій ситуації набуті знання і досвід, що є первинним завданням під час підготовки майбутнього фрахівця. Натепер цій проблематиці приділяється увага, але ії не досить для повноцінного фрормування профресійних компетенцій майбутніх фрахівців технічної галузі, враховуючи щорічне зменшення годин з дисциплін гуманітарного напряму.

Метою статті $\epsilon$ аналіз наукових уявлень про явище «професійна компетентність». Здійснення зазначеної мети передбачає вирішення таких завдань, як: аналіз наявних визначень поняття «компетентність», «профресійна компетентність»; вивчення структури і професійної компетентності особистості; визначення ролі гуманітарних дисциплін під час підготовки студентів; визначення та обґрунтування їх фрункцій у процесі життєдіяльності особистості.

Виклад основного матеріалу. Студент намагається знайти своє місце в житті відповідно до власних уподобань, інтересів та можливостей. I тільки компетентнісний підхід спрямований на саморозвиток і самовиховання студента, уміння самостійно осмислювати різні поняття, правила, теорії, формування пізнавальних, комунікативних, організаційних умінь, креативного способу мислення. Використання знань на практиці сприяє більш цілісному уявленню про світ та його взаємозв'язки. Компетентність означає загальну здатність молодої людини до професійної праці й успішної життєдіяльності, що ґрунтується на здобутих знаннях, уміннях, досвіді та цінностях, 
здатності до продуктивного здійснення життя як індивідуального життєвого проєкту.

Профресійна компетентність фрахівця, як зазначає М.Ю. Кадемія, «передбачає розв'язання різного роду проблем, завдань на основі наявного досвіду, знань і цінностей, а професійні компетенції передбачають здатність людини успішно діяти в процесі своєї професійної діяльності, що робить можливим бути профресійно успішним будь-якого випускника навчального закладу» [6, с. 39].

Поєднання гуманітарної підготовки з профресійною кваліфікацією майбутніх фрахівців технічної галузі - одна 3 найактуальніших проблем діяльності вищих навчальних закладів технічного профрілю. Характерною особливістю сучасного українського суспільства $€$, на жаль, поступова втрата духовно-моральних, історичних та культурногуманітарних пріоритетів і цінностей.

Реалізація повною мірою компетентності людини можлива за наявності фрахової підготовки, діяльності в конкретній галузі й володіння відповідними компетенціями як цілісної сукупності досягнень на основі змісту соціально значущих і важливих властивостей професіонала. Виділяють чотири блоки компетентностей: базовий (інтелектуально, інфрормаційно забезпечуючий); особистісний; соціальний (забезпечення життєдіяльності та взаємодії в соціумі); професійний (адекватність виконання фрахової діяльності). На думку вчених, до базових компетентностей професійної підготовки належать: загальнонаукові; соціально-економічні; громадянсько-правові; інфрормаційно-комунікативні; політехнічні; спеціальні. Професійна компетентність розуміється як інтегративна система властивостей і якостей особистості, професійних знань, умінь, навичок, здібностей виконання фахової діяльності на високому рівні з використанням суспільно відомих і важливих, адаптованих компетенцій, засобів, методів та досвіду, що характеризує відповідальність, дієву обізнаність і загальну освіченість, спрямованість на перспективу й ефективність у роботі, забезпечує впевненість і здатність досягати прогнозованих результатів.

Профресійна компетентність інженера - це показник готовності, система компетенцій, інтегрованих знань, умінь, навичок, здібностей і досвіду, необхідних для виконання посадових обов'язків і функцій, розв'язання виробничих завдань. Розглядаючи питання компетентнісного підходу в організації навчально-виховного процесу вищої школи, на перше місце новітні науковці ставлять не поінформованість студента, а вміння розв'язувати проблеми, що виникають у пізнавальній, технологічній і психічній діяльності, у сорерах етичних, соціальних, правових, професійних, особистих взаємин [4, с. 267].

Перехід України на нову стратегію соціального розвитку та її входження до міжнародного освіт- нього простору роблять надзвичайно актуальною проблему підготовки майбутнього інженера, який володіє спеціальними компетенціями або професійно-функціональними знаннями і уміннями, які забезпечують прив'язку до конкретного об'єкта, предмета праці фрахівця, готового до творчої професійної діяльності, що постійно оновлюється.

Основною особливістю вітчизняного варіанту компетентнісного підходу у вищій освіті є практикоорієнтованість із формуванням готовності й уміння вирішувати певні проблеми і завдання професійної та соціальної діяльності, розробка міждисциплінарних і багатодисциплінарних навчальних курсів, що відповідають викликам професійної, соціальної, практичної життєдіяльності сучасного суспільства. У зв'язку з цим головним результатом підготовки майбутнього інженера має стати не стільки система знань, умінь і навичок, скільки універсальна інтегральна характеристика, що включає результати навчання, систему сорормованих цінностей, мобілізаційну готовність до того або того виду діяльності; соціальні норми поведінки і засвоєні механізми взаємодії з навколишньою дійсністю [5, с. 222].

У сучасних умовах розвитку вищої технічної школи виховати інженера-інтелігента можна тільки за умови створення особливого культурного середовища навчання й виховання, що пов'язано 3 духовно-моральним, культурно-естетичним насиченням змісту всього педагогічного процесу. У зв'язку з цим істотно зростає роль системних, міждисциплінарних знань людини, необхідних для раціонального й осмисленого оперування з нескінченними потоками різноманітних знань і даних 3 метою вирішення нових, нестандартних проблем. У цій новій парадигмі найголовніше місце відводиться аналітичним здібностям інженера та вченого, тобто його спроможності шукати і знаходити необхідну інфрормацію, точно формулювати проблеми і гіпотези, вбачати в сукупностях даних певні закономірності, знаходити розв'язок складних міждисциплінарних задач [7, с. 6].

Низка дослідників розглядає загальні напрями розв'язання питань гуманітарної підготовки фрахівців у вищих навчальних технічних закладах, що $€$ складником педагогічної системи вищої освіти, яка, своєю чергою, базується і здійснюється на загальнопедагогічних принципах навчання й виховання.

Гуманітарна підготовка є важливим складником процесу професійної підготовки майбутнього інженера. Вона $€$ системотвірним фрактором процесу підготовки студентів вищих технічних закладів освіти, наскрізною ланкою, яка пронизує кожен ії компонент [8, с. 117]. Для безпосередньої реалізації гуманітарної підготовки майбутніх інженерів викладач має володіти гуманітарною компетентністю. Саме поняття «гуманітарна компетентність» 
ученими розуміється як рівень досвідченості, достатній для самоосвіти і самостійного вирішення певних проблем; комплекс універсальних знань, які відрізняються широким рівнем узагальнення необхідні для соціально-продуктивної діяльності будь-якої сучасної людини [9, с. 11].

Філософрія відкриває шлях до пізнання та пояснює сутність культури в її найбільш узагальненому уявленні. Соціологія виявляє закономірності процесу їі фрункціонування в суспільстві, особливості культурного рівня різних груп. Психологія дає можливість глибше зрозуміти специфріку культурнотворчої діяльності людини, механізм сприйняття нею цінностей культури, становлення духовного світу. Етнографрія сприяє осягненню національноетнічної унікальності культур народів світу, утвердженню ролі культури в міжнаціональних відносинах. Мистецтво розкриває особливості понять проявів духовного життя в єдиному смисловому контексті [10, с. 37].

Саме тому під час проєктування змісту технічної освіти необхідно враховувати сучасні потреби та вимоги, а також визначені принципи освіти, що дасть йому цілеспрямований, системний характер, створивши при цьому спеціальні педагогічні умови для формування і розвитку гуманітарної компетентності майбутніх інженерів. Таким чином, одним із провідних чинників відбору змісту підготовки спеціалістів є синтезування профеесійних і гуманітарних знань та взаємозв'язок перспектив розвитку системи освіти, виробництва, техніки, праці, ринку кваліфрікованих кадрів і культури. Кожному етапу розвитку суспільства притаманні свої соціально-економічні та науково-технічні проблеми. Їхнє розв'язання потребує нових підходів, що враховують динаміку змін у життєдіяльності різних соціальних систем [11, с. 9-22].

Вищезазначене передбачає обґрунтування наукових підходів, педагогічних умов, принципів, розробки моделі і способів проєктування системи гуманітарної підготовки майбутніх інженерів у процесі вивчення відповідних дисциплін у вищих технічних навчальних закладах. Саме такий підхід може забезпечити високий рівень сорормованості гуманітарної компетентності випускників закладів вищої освіти.

Гуманітарна компетентність передбачає сорормованість гуманістичного бачення світу, духовноестетичних цінностей, власної думки й переконання, здатність стверджувати та відстоювати їх.

Водночас слід наголосити на необхідності літератури для саморозвитку й самореалізації духовного світу людини, для досягнення гармонійних стосунків індивідуума 3 навколишнім світом, осмислення внутрішньої єдності систем цінностей, відображених у літературі, розвитку здатності до критичного мислення, вміння протидіяти антигуманістичним тенденціям у сучасній культурі, задоволення духовних запитів студентів, зумовлених психологічними особливостями їхнього віку [12, с. 73].

Жоден навчальний процес не може забезпечити увесь обсяг необхідних знань, умінь та навичок. Під час підготовки фрахівця у технічному вищому навчальному закладі потрібно дбати не лише про професійну підготовку студентів, а й намагатися зберегти в них те вічне, яке закладається в кожну людину, - її духовність, культуру. На основі аналізу новітніх наукових праць поняття «гуманітарна компетентність» визначають як інтегративне утворення особистості, що вміщує знання про світову і національну культуру, ціннісно-мотиваційну сореру майбутнього фрахівця, уміння застосовувати їх у процесі творчого розв'язання практичних задач у професійній діяльності, навички соціокультурного спілкування, здатність до рефлексії, правильного орієнтування в сучасному соціокультурному просторі, а також критичне мислення, прагнення кожного індивіда до саморозвитку та самоосвіти, що проявляється у готовності до конструктивної культуротворчої діяльності в умовах культурних відмінностей між народами [13, с. 120].

На думку вчених, соціально-наукові та гуманітарні знання загалом сприяють зняттю суперечностей між людиною та технікою, людиною та природою, оскільки дають такий рівень профресійної культури, який дає змогу ще на етапі проєктування мінімізувати негативні соціальні та моральні наслідки інженерної діяльності; фрормують здатність до адекватної оцінки та прийняття правильного рішення в критичній ситуації; актуалізують людський, а не лише технічний сенс інженерної профресії. Соціально-гуманітарний компонент в інженерному мисленні та діяльності відіграє певною мірою захисну роль. Саме тому до проєктування змісту технічної освіти необхідно підійти 3 нових позицій і відповідно до вимог гуманістичного принципу надати йому цілеспрямований, системний характер, створивши при цьому спеціальні педагогічні умови для фрормування і розвитку гуманітарної компетентності майбутніх інженерів. Таким чином, одним із провідних фракторів відбору змісту підготовки спеціалістів є синтезування і діалектичний взаємозв'язок перспектив розвитку системи освіти, виробництва, техніки, праці, ринку кваліфікованих кадрів і культури.

Гуманітарний підхід вивчає феномен культури і $€$ стрижнем розуміння людини, її свідомості й життєдіяльності, культуротворчості. Це насамперед гуманістична позиція, що визнає людину суб'єктом культури, її головною дійовою особою. Сутність гуманітарного підходу у процесі навчання у вищому технічному навчальному закладі полягає у визнанні особистості студента вищою цінністю, здатною реалізувати культурно-етнічні ідеї в педагогічному процесі; взаєморозумінні та взаємодовірі між 
учасниками як суб'єктами педагогічного процесу; орієнтації майбутніх фрахівців у моральних, естетичних, екологічних, правових, профессійних та інших цінностях; індивідуалізації процесів оволодіння культурою та створенні елементів культури в процесі навчання та виховання. Реалізація гуманітарного підходу вимагає від викладачів вищих технічних навчальних закладів міцних знань культури свого та інших народів, що забезпечує фрормування у студентів толерантності, поваги до людей та відповідність морально-етичним нормам поведінки. Гуманістична, особистісна орієнтація професійної підготовки передбачає звернення головної уваги на ціннісно-мотиваційну домінанту особистості, котра визначає спрямованість останньої, зокрема професійну. Головною домінантою у роботі зі студентами має стати орієнтація на успішність у навчанні з наголосом на її процес і результат.

Безумовно, випускник університету має бути різнобічно освіченим, оскільки нульові знання в інших галузях, крім його фрахової, не дозволять йому стати сучасним професіоналом, досягнути успіху в певному виді діяльності. Нині вже не потрібні докази для того, що саме існування нашого майбутнього залежить від визнання цінності людини як особистості, її гуманізму, утвердження права на її вільний розвиток та прояв своїх здібностей.

Висновки. Високий рівень життєвої і профресійної компетентності студента сприяє досягненню особистого успіху, ефективній самореалізації в багатьох соціальних сорерах, зростанню продуктивності в різних галузях економіки, що позитивно позначається на розвитку суспільства. Компетентність фрормується насамперед завдяки власним зусиллям людини як наслідок саморозвитку, професійного та особистісного зростання, синтезу профресійного та життєвого досвіду. Випускник $3 В О$ має здобути достатні навички самостійної роботи, уміння планувати свій робочий час і займати активну позицію стосовно професійної діяльності. Отже, можемо зробити загальний висновок, що гуманітарна компетентність майбутніх інженерів - це якісна, інтегративна професійно-особистісна характеристика, що визначається наявністю: загальнокультурних та національно-культурних знань та вмінь виокремлювати спільне й відмінне в культурах різних країн, світосприйнятті їх носіїв, духовно-моральні властивості та мотиваційноціннісні орієнтації; здатності до національної самоідентифрікації, інтеграції й рефрлексії, готовності здійснювати культуротворчу діяльність, вести міжкультурний діалог; усвідомлення себе та кожної особистості як носія певної етнокультури, що дає змогу ефективно протидіяти антигуманістичним тенденціям у професійній діяльності і повсякденному житті.

\section{БІБЛІОГРАФІЧНИЙ СПИСОК:}

1. Андреев А. Знания или компетенции? Высшее образование в России: научно-педагогический журнал. 2005. № 2. С. 3-12.

2. Ахмедьянова Г.Ф. Инженерная компетентность как результат интеграции творческого и технологического компонентов обучения. Фундаментальные исследования. 2011. № 8. С. 13-16.

3. Дичковський С.I. Педагогічні засади культурологічної підготовки майбутніх інженерів засобами дистанційного навчання : автореф. дис. на здобуття наук. ступеня канд. пед. наук : спец. 13.00.04 «Теорія і методика профресійної освіти». Київ. 2009. 21 с.

4. Кадемія М.Ю. Формування профресійної компетенції майбутнього фрахівця. URL: http://www.kpi. kharkov.

5. Коваленко О.Е. Професійно-педагогічна підготовка майбутнього інженера-педагога. Теоретичні та методичні засади розвитку педагогічної освіти: педагогічна майстерність, творчість, технології. Харків. 2007. С. 115-120.

6. Кравец А.С. Гуманизация и гуманитаризация высшего образования. Москва : Наука. 1998. 156 с.

7. Кузьміченко І.О. Формування соціально-професійної компетентності майбутнього інженера. Вісник ЛнУ імені Тараса Шевченка. Луганськ. 2009. № 23 (186). ․ 3. С. 220-224.

8. Музальов О. Культурологічна підготовка учнів професійно-технічних навчальних закладів. Педагогіка і психологія профресійної освіти. 2003. № 1. C. 69-79.

9. Нагорна Н.В. Формування у студентів понять компетентності й компетенції. Виховання і культура. 2007. № 1-2 (11-12). С. 266-268.

10. Ничкало Н.Г. Неперервна профресійна освіта як фрілософсьька та педагогічна категорія. Неперервна професійна освіта: теорія і практика. 2001. Вип. 1. 212 с.

11. Яценко С.Л. Сутнісні аспекти особистісно орієнтованої освіти. Проблеми освіти : наук-метод. зб. Інститут інноваційних технологій і змісту освіти МОН України. Київ, 2015. № 85. Спецвипуск. С. 116-122. 